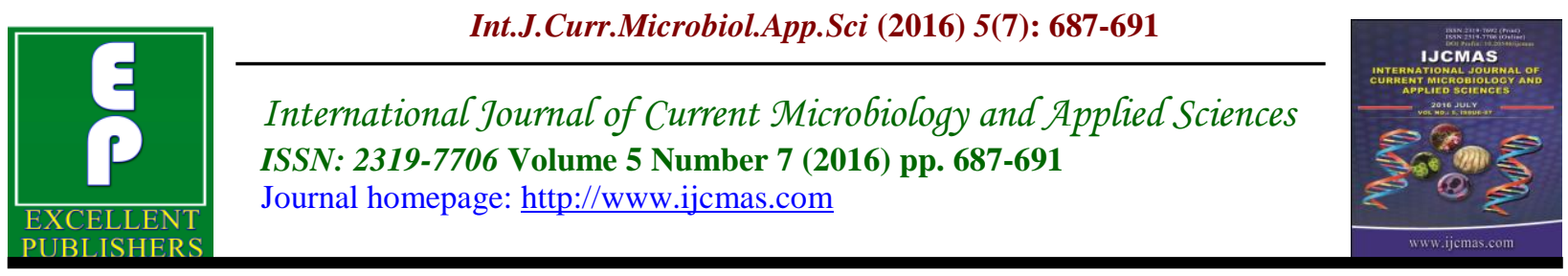

Original Research Article

http://dx.doi.org/10.20546/ijcmas.2016.507.078

\title{
Antimicrobial Activity of Different Extracts of Leaves Bark and Roots of Moringa oleifera (Lam)
}

\author{
D.A.C.K. Dalukdeniya, K.L.S.R. De Silva and R.M.U.S.K. Rathnayaka* \\ Department of Food Science and Technology, Faculty of Applied Sciences, Sabaragamuwa \\ University of Sri lanka, P.O.Box 02, Belihuloya, Sri Lanka \\ *Corresponding author email id:
}

\begin{tabular}{|c|c|}
\hline \multicolumn{2}{|c|}{ A B S T R A C T } \\
\hline & $\begin{array}{l}\text { The main aim of this study was to evaluate the antibacterial activity of aqueous } \\
\text { extracts, chloroform extracts and methanol extracts obtained from leaves, bark and }\end{array}$ \\
\hline & $\begin{array}{l}\text { roots of Moringa oleifera (Lam) against four food borne microbial pathogens, } \\
\text { Salmonella enteritica, Vibrio parahaemolyticus, Escherichia coli and Listeria }\end{array}$ \\
\hline $\begin{array}{l}\text { Moringa oleifera, } \\
\text { antibacterial } \\
\text { compounds, } \\
\text { food borne } \\
\text { pathogens, } \\
\text { plant extracts. }\end{array}$ & $\begin{array}{l}\text { monocytogenes. In general, extracts obtained by all extraction methods showed } \\
\text { antimicrobial activity against all tested microorganisms. Lowest and highest } \\
\text { antibacterial activity was shown by aqueous extraction and chloroform extraction } \\
\text { of residue obtained after aqueous extraction. Highest antibacterial activity was } \\
\text { shown by chloroform extraction of residue obtained after aqueous extraction } \\
\text { against Salmonella enteritica. Listeria monocytogenes was found to be the most }\end{array}$ \\
\hline Article Info & $\begin{array}{l}\text { resistant organism to all types of extracts. Higher antibacterial activity was shown } \\
\text { against gram negative bacteria compared to gram positive bacteria tested. }\end{array}$ \\
\hline $\begin{array}{l}\text { Accepted: } \\
\text { 22 June } 2016 \\
\text { Available Online: } \\
\text { 10 July } 2016\end{array}$ & $\begin{array}{l}\text { According to the results of the study, chloroform extraction was found to be the } \\
\text { best extraction method to extract antimicrobial compounds from Moringa oleifera } \\
\text { (Lam). Bark of the plant shown to be containing higher amount of antimicrobial } \\
\text { compounds compared to leaves and roots of the pant. In conclusion, Moringa } \\
\text { oleifera (Lam) extracts found to be containing chemical compounds useful in food } \\
\text { preservation and development of drugs against food borne microbial pathogens. }\end{array}$ \\
\hline
\end{tabular}

\section{Introduction}

In many countries different types of plant extracts have been used in traditional medical systems to treat for microbial disease. Phytochemicals present in those plants having antimicrobial and antioxidant properties are the reason for this ability to use them in disease treatments (Akinmoladun et al.,, 2007). Antimicrobial activities of some phytochemicals present in such plants have been investigated and the possibility of using them to develop new antimicrobial drugs has also been studied (Nascimento et al.,, 2000). There is a growing attention for the development of new antimicrobial drugs because pathogenic microorganisms becoming resistance to antibiotics which are in use. Extracts of plants which are obtained from the plant used in traditional medicine are a good source of new antimicrobial drug discoveries. As such investigations on the 
composition, activity, as well as validation of the use of extracts obtained from medicinal plant is important (Nair et al., 2006). Many researchers have been carried out to investigate the antimicrobial activity of different plant extracts (Rathnayaka., 2013, Jed et al.,, 2005, Gopalakrishnan et al.,, 2016).

Moringa oleifera (Lam) which is belonging to the mongeneric family Moringaceae is native to the sub-Himalayan tracts of India, Pakistan, Bangladesh and Afghanistan. This tree is now has become cultivated and naturalized in many locations of the tropics (Jed, 2005). It has been reported that different preparations of this plant having antibiotic, antitrypanosomal, hypotensive, antispasmodic, antiulcer, anti-inflammatory, hypo-cholesterolemic, and hypoglycemic activities. Fruits and leaves of the plant Moringa oleifera (Lam) are used as a food while all parts of the plants used in traditional medicine.

A few researchers have investigated the antimicrobial activity of Moringa oleifera (Lam) extracts against some pathogenic bacteria (Ashok et al.,, 2014, Elangovan et al.,, 2014.). However, studies on the antibacterial activity of Moringa extracts on food borne microbial pathogens are limited. As such, in this study we have evaluated aqueous extracts, chloroform extracts and methanol extracts obtained from leaves, bark and roots of Moringa oleifera (Lam) for their antimicrobial activity against four food borne pathogens.

\section{Materials and Methods}

\section{Plant materials}

Plant materials namely, leaves, bark and roots of Moringa oleifera (Lam) plant were collected from Balangoda, Sri Lanka. Those were then grinded using a mechanical grinder and stored in airtight containers until further use. However, those were used for extractions within 30 min after grinding.

\section{Aqueous extraction}

From each prepared leaves, bark and roots samples of Moringa oleifera (Lam) $200 \mathrm{~g}$ were mixed with $500 \mathrm{~mL}$ of water and kept $8 \mathrm{~h}$ at ambient temperature. Then whole mixture was filtered using a cheese cloth and obtained extracts was centrifuged. After centrifugation, supernatants were labeled as "Extract AL" "Extract AB" and "Extract AR" for the extracts of leaves, bark and root respectively. Those were then used for the antibacterial activity assay. Residue obtained from filtration and centrifugation were mixed and used for $\mathrm{CHCl}_{3}$ extraction.

\section{Chloroform extraction}

The residues obtained after aqueous extraction were separately used for the chloroform extraction. Those were mixed with equal volume of chloroform and kept $24 \mathrm{~h}$ at ambient conditions. Then, mixtures were filtered using cheese cloth and extracts were obtained. Extract obtained were labeled as "Extract BL", "Extract BB" and "Extract BR" for the residues of leaves, bark and root respectively. The obtained extracts were used for antibacterial activity assay and residues were separately used for alcoholic extraction.

\section{Alcoholic extraction}

All three types of residues obtained after chloroform extraction were separately treated with equal volume of methanol and kept for $24 \mathrm{~h}$ at ambient conditions. Then the mixtures were filtered using cheese cloth and extracts were obtained. Extract were labeled as "Extract CL", "Extract CB" and 
"Extract CR" for the residues of leaf, bark and root respectively. The obtained extracts were then used for antibacterial activity assay.

\section{Preparation of microbial cultures}

Four bacteria used in this study Vibrio parahaemolyticus, Salmonella enterica, Escherichia coli, and Listeria monocytogenes were separately enriched by culturing for 24 hours at $37{ }^{\circ} \mathrm{C}$ in an universal culture medium, Tryptic Soy Broth Yeast Extract medium (TSBYE). Each culture was then divided to two potions and one potion was stored at refrigerated conditions. The other potion was serially diluted $\left(10^{-1}-10^{-10}\right)$ in sterile distilled water and enumerated in Tryptic Soy Agar (TSA) plates. Bacterial concentration was estimated by calculating the average number of colonies on plates containing 30 to 300 colonies. Then using the stored cultures dilutions of each culture containing $10^{3} \mathrm{CFU}$ / $\mathrm{mL}$ were prepared and used in the antimicrobial activity test.

\section{Antibacterial activity assay}

Prepared cultures of Salmonella enteritica, Vibrio parahaemolyticus, Escherichia coli and Listeria monocytogenes were used for this assay. Form each culture, $1 \mathrm{~mL}$ were cultured on nutrient agar plates. Then with the help of a sterile cork borer wells of $4 \mathrm{~cm}$ diameter were prepared on each of those plates. Fifty micro liters of each Moringa oleifera (Lam) extracts were separately added to wells in plates which were inoculated with each bacterium. Then those were incubated at $37{ }^{\circ} \mathrm{C}$ for $24 \mathrm{~h}$. after incubation clear zone of inhibition were observed around the wells of the plates. Diameters of those inhibition zones were measured. Antibacterial activity of each Moringa oleifera (Lam) extracts against four tested pathogenic microorganisms was evaluated using those measurements.

\section{Results and Discussion}

Antibacterial activity of different Moringa oleifera (Lam) extracts against four food borne microbial pathogens, Salmonella enteritica, Vibrio parahaemolyticus, Escherichia coli and Listeria monocytogenes were studied. Results of the study are shown in the table 1.

All different extracts tested in this study shown to possess antimicrobial activity, in different level, against the all tested microbial pathogens. Out of all tested extracts, extracts obtained by chloroform extraction of the residual of aqueous extraction shown to be with highest antimicrobial activity while extracts obtained by aqueous extraction shown to be with the lowest antimicrobial activity (table 1). These results are in agreement with the results of similar studies carried out by other authors for other microbes (Aiyegoro et al.,, 2008; Kalpana et al.,, 2013). Further, in similar study (Ashok et al., 2014) which was carried out using different types of microorganism different results has also been reported. In that study, aqueous extract has shown the highest antimicrobial activity while chloroform extract has shown no antimicrobial activity against the tested microorganisms. However, in many studies, including our study, it has been reported that the extract obtain by aqueous extraction possess lowest antimicrobial activity while chloroform extraction possess the highest antimicrobial activity. As such, chloroform extraction can be recognized as the best method to extract antimicrobial compounds from plant parts of Moringa oleifera (Lam).

Studies have been carried out to investigate the antimicrobial activity of different parts 
of Moringa oleifera (Lam) plant. In those studies different extracts obtained from Moringa oleifera (Lam) leaves (Ashok et al., 2014, Elangovan et al., 2014, Kalpana et al.,, 2013), bark (Zaffer et al.,, 2014) and roots (Raj et al., 2011) has been studied for their antimicrobial activity against different types of microorganisms. However, all those plant parts have not been studied in a one research and as such comparative information of the availability of antimicrobial compound in each part of the plant is not available. Hence, in our study, extract obtained from different parts of Moringa oleifera (Lam) plant were comparatively studied. The results of the study indicate that the antimicrobial compound is present in high quantities in the bark compared to other parts of the plant (Table 1).

Table.1 Antibacterial activity of different Moringa oleifera (Lam) extracts against Salmonella enteritica, Vibrio parahaemolyticus, Escherichia coli and Listeria monocytogenes

\begin{tabular}{|l|l|l|l|l|}
\hline \multirow{2}{*}{ Extract } & \multicolumn{4}{|c|}{ Microorganisms } \\
\cline { 2 - 5 } & $\begin{array}{l}\text { Salmonella } \\
\text { enteritica }\end{array}$ & $\begin{array}{l}\text { Vibrio } \\
\text { parahaemolyticus }\end{array}$ & $\begin{array}{l}\text { Escherichia } \\
\text { coli }\end{array}$ & $\begin{array}{l}\text { Listeria } \\
\text { monocytogenes }\end{array}$ \\
\hline Extract AL & ++ & ++ & ++ & + \\
\hline Extract AB & +++ & +++ & +++ & ++ \\
\hline Extract AR & +++ & ++ & +++ & ++ \\
\hline Extract BL & +++ & +++ & +++ & ++ \\
\hline Extract BB & +++++ & ++++ & ++++ & +++ \\
\hline Extract BR & ++++ & +++ & +++ & ++ \\
\hline Extract CL & +++ & +++ & ++ & + \\
\hline Extract CB & ++++ & +++ & +++ & ++ \\
\hline Extract CR & ++++ & +++ & +++ & ++ \\
\hline
\end{tabular}

,,,++++++++++ , and +++++ are zone diameter less than $5 \mathrm{~mm}, 5-10 \mathrm{~mm}, 10-15 \mathrm{~mm}, 15-20 \mathrm{~mm}$ and higher than $20 \mathrm{~mm}$ respectively

In the present study highest antimicrobial activity of extracts was shown against Salmonella enteritica, and out of four bacteria tested, Listeria monocytogenes was found to be the most resistant organism to all types of extracts. All types of Moringa oleifera (Lam) extract have shown antimicrobial properties against both gram negative bacteria (Salmonella enteritica, Vibrio parahaemolyticus, Escherichia coli) as well as gram positive bacteria (Listeria monocytogenes). Further those extracts shown to be with higher antibacterial activity against gram negative bacteria compared to gram positive bacteria.

In general, according to the results of the study, all tested parts of Moringa oleifera
(Lam) plant were found to be containing chemical compounds which can be used as antimicrobial compounds against food borne microbial pathogens. Out of those bark was found to be containing high amount of antimicrobial compound and extraction to chloroform was found to be the most effective way to extract those antimicrobial compounds. These results confirm the use of Moringa oleifera (Lam) plant in traditional medicine and possibility to use the extracts of Moringa oleifera (Lam) plant for new drug discoveries against food borne microbial pathogens. Further, these results show the possibility of using Moringa oleifera (Lam) plant parts in food preservation. 
In conclusion, antimicrobial activity against all tested food borne microbial pathogens was shown by the plant extract obtained by different methods from leafs, bark and roots of Moringa oleifera (Lam). Those extracts were found to be more effective in controlling tested gram negative bacteria than gram positive bacteria. Chloroform extraction was found to be the best extraction method to extract antimicrobial compounds from all parts of Moringa oleifera (Lam) plant. In conclusion, the results of the study confirm the use of Moringa oleifera (Lam) plant parts in traditional medicine and the possibility to use extracts of Moringa oleifera (Lam) plant in food preservation and new antimicrobial drug discoveries.

\section{References}

Aiyegoro, O.A., D.A., Akinpelu, A.J., Afolayan, Okoh, A.I. 2008. Antibacterial activities of crude stem bark extracts of Distemonathus benthamianus Baill. $J$. Bio. Sci., 8(2): 356-361.

Akinmoladun, A.C., Ibukun, E.O., Afor, E., Obuotor, E.M., Farombi, E.O. 2007. Phytochemical constituent and antioxidant activity of extract from the leaves of Ocimum gratissimum. Sci. Res. Essay, 2: 163-166.

Ashok, V., Gomashe, P.A.G., Megha, P.J., Neeta, A.D. 2014. Antimicrobial Activity of Indian Medicinal Plants: Moringa oleifera and Saraca indica Int. J. Curr. Microbiol. App. Sci., 3(6): 161-169.

Elangovan, M., Dhanarajan. M.S., Rajalakshmi, A., Jayachitra, A., Mathi, P., Bhogireddy N. 2014. Analysis of Phytochemicals, Antibacterial and Antioxidant activities of
Moringa oleifera Lam. Leaf extract- an in vitro study. Int. J. Drug Dev. \& Res., 6 (4): 173-180.

Gopalakrishnan, L., Doriya, K., Kumara, D. S. 2016. Moringa oleifera: A review on nutritive importance and its medicinal application. Food Sci. Human Wellness, 5: 49-56.

Jed, W., Fahey, S.D. 2005. Moringa oleifera: A Review of the Medical Evidence for Its Nutritional, Therapeutic, and Prophylactic Properties. Part1. Trees for Life J., 1: 5.

Kalpana, S., Moorthi, S., kumara, S. 2013. Antimicrobial activity of different extracts of leaf of Moringa oleifera (Lam) against gram positive and gram negative bacteria. Int. J. Curr. Microbiol. App. Sci., 2(12): 514-518.

Nair, R., Chanda, S. 2006. Activity of some medicinal plants against certain pathogenic bacterial strains. Indian $J$. Pharmacol., 38(2): 142-144.

Nascimento, G.G.F., Locatelli, J., Freitas, P.C., Silva, G.L. 2000. Antibacterial activity of plant extracts and phytochemicals on antibiotic resistant bacteria. Braz. J. Microbiol., 31(4): 247-256.

Raj, A.J., Gopalakrishnan, V.K., Yadav, S.A., Dorairaj, S. 2011. Antimicrobial Activity of Moringa oleifera (Lam.) Root Extract. J. Pharm. Res., Vol. 4 Issue 5, p1426.

Rathnayaka, R.M.U.S.K. 2013. Antibacterial Activity of Ocimum Sanctum Extracts against Four Food-Borne Microbial Pathogens. Scholars J. Appl. Med. Sci., 1(6), pp.774-777.

Zaffer, M., Ahmad, S., Sharma, R., Mahajan, S., Gupta, A., Agnihotri, R. K. 2014. Antibacterial activity of bark extracts of Moringa oleifera Lam. against some selected bacteria. Pak J. Pharm. Sci., 27(6):1857-62.

\section{How to cite this article:}

Dalukdeniya, D.A.C.K., K.L.S.R. De Silva and Rathnayaka, R.M.U.S.K. 2016. Antimicrobial Activity of Different Extracts of Leaves Bark and Roots of Moringa oleifera (Lam). Int.J.Curr.Microbiol.App.Sci. 5(7): 687-691. doi: http://dx.doi.org/10.20546/ijcmas.2016.507.078 